\title{
Toxicity and Binding Profile of Lectins from the Genus Canavalia on Brine Shrimp
}

\author{
Francisco Vassiliepe Sousa Arruda, ${ }^{1}$ Arthur Alves Melo, ${ }^{2}$ \\ Mayron Alves Vasconcelos, ${ }^{2}$ Romulo Farias Carneiro, ${ }^{2}$ Ito Liberato Barroso-Neto, ${ }^{2}$ \\ Suzete Roberta Silva, ${ }^{3}$ Francisco Nascimento Pereira-Junior, ${ }^{2}$ Celso Shiniti Nagano, ${ }^{3}$ \\ Kyria Santiago Nascimento, ${ }^{2}$ Edson Holanda Teixeira, ${ }^{1}$ Silvana Saker-Sampaio, ${ }^{3}$ \\ Benildo Sousa Cavada, ${ }^{2}$ and Alexandre Holanda Sampaio ${ }^{3}$ \\ ${ }^{1}$ Integrated Laboratory of Biomolecules (LIBS-BioMol Group), Department of Pathology and Legal Medicine, \\ Federal University of Ceará, 62042-280 Fortaleza, CE, Brazil \\ ${ }^{2}$ Laboratory of Biologically Actives Molecules, Department of Biochemistry and Molecular Biology, Federal University of Ceará, \\ 60440-970 Fortaleza, CE, Brazil \\ ${ }^{3}$ Marine Biochemistry Laboratory, Fishing Engineering Department, Federal University of Ceará, 60440-970 Fortaleza, CE, Brazil \\ Correspondence should be addressed to Benildo Sousa Cavada; bscavada@ufc.br
}

Received 16 July 2013; Accepted 24 October 2013

Academic Editor: Daiana Avila

Copyright (C) 2013 Francisco Vassiliepe Sousa Arruda et al. This is an open access article distributed under the Creative Commons Attribution License, which permits unrestricted use, distribution, and reproduction in any medium, provided the original work is properly cited.

\begin{abstract}
Lectins are sugar-binding proteins widely distributed in nature with many biological functions. Although many lectins have a remarkable biotechnological potential, some of them can be cytotoxic. Thus, the aim of this study was to assess the toxicity of five lectins, purified from seeds of different species of Canavalia genus. In order to determine the toxicity, assays with Artemia nauplii were performed. In addition, a fluorescence assay was carried out to evaluate the binding of lectins to Artemia nauplii. In order to verify the relationship between the structure of lectins and their cytotoxic effect, structural analysis was carried out to evaluate the volume of the carbohydrate recognition domain (CRD) of each lectin. The results showed that all lectins exhibited different toxicities and bound to a similar area in the digestive tract of Artemia nauplii. Concerning the structural analysis, differences in spatial arrangement and volume of CRD may explain the variation of the toxicity exhibited by each lectin. To this date, this is the first study that establishes a link between toxicity and structure of CRD from Diocleinae lectins.
\end{abstract}

\section{Introduction}

Lectins are sugar-binding proteins widely distributed in nature in organisms such as viruses, bacteria, fungi, plants, and animals [1]. Some of these proteins bind mono- and oligosaccharides specifically and reversibly but are devoid of catalytic activity and, in contrast to antibodies, are not products of an immune response [2]. Lectins have many biological functions, such as host defense, cell-cell interaction, glycoprotein folding, symbiosis, regulation of cell growth, apoptosis, fertilization, and other functions $[3,4]$. Lectins purified from the Leguminosae family are the most extensively studied carbohydrate-binding proteins [5]. The subtribe Diocleinae has lectins that are multimeric structures composed of identical monomers of $25.5 \mathrm{kDa}$ and exhibit a $\mathrm{pH}$-dependent equilibrium between dimer and tetramer conformations. Diocleinae lectins also share the same carbohydrate recognition specificity for D-mannose and Dglucose, require divalent ions such as $\mathrm{Ca}^{2+}$ and $\mathrm{Mn}^{2+}$ to be biologically active, and contain a hydrophobic cavity that binds to phytohormones and other hydrophobic ligands. Despite their high similarity, these ConA-like lectins induce different responses in biological assays; for example, when tested for stimulation of human lymphocyte proliferation in vitro, ConBr had a higher proliferation index than ConA, possibly due to minor changes in binding specificities [6]. 
A broad range of lectins has been found to exhibit toxic and cytotoxic activities in several different assays. These effects include in vitro cytotoxicity in cultured lymphoid cells [7], tumor cells [8], and $\mathrm{T}$ cells [9] and in vivo toxicity after injection of the lectin into the peritoneal cavity of mice and lethality in the brine shrimp Artemia sp. [10]. In particular, the Artemia lethality test $[11,12]$ has been used successfully to determine the toxicity of bioactive compounds that have a variety of pharmacological activities, including anticancer agents, antivirals, insecticides, pesticides, and anti-HIV compounds [13-15]. The Artemia nauplii were used because they are highly sensitive. In addition, the cysts can be easily obtained, hatched, and stored at room temperature for several months without losing their viability [16]. In the present work, the toxicity of five lectins isolated from seeds of plants from the genus Canavalia was evaluated using the Artemia lethality test.

\section{Materials and Methods}

2.1. Artemia Nauplii Hatching. The Artemia cysts were hatched in artificial seawater at $28^{\circ} \mathrm{C}$ under constant lighting and strong aeration. The cysts were incubated in a polyethylene cylindroconical tube with $1 \mathrm{~g}$ cysts per liter of artificial seawater. This hatching condition simulates Artemia's natural environment, shallow seawater. After a period of $24 \mathrm{~h}$, the aeration was halted, and the lighting was directed to the bottom of the hatching vessel. Due to the phototropic nature of the nauplii, they migrate in the direction of the light to the bottom of the tube, while the unhatched cysts float. The nauplii are then collected and used for bioassays.

2.2. Purification of Lectins. Lectins from Canavalia ensiformis (ConA), C. brasiliensis (ConBr), C. boliviana (ConBol), C. grandiflora (ConGF), and C. maritima (ConM) were extracted from air-dried ground seeds collected in Fortaleza, CE, Brazil, and defatted with $\mathrm{n}$-hexane. The protein extract was obtained by continuous stirring with $0.9 \% \mathrm{NaCl}$ $(1: 10 \mathrm{w} / \mathrm{v})$ at $20^{\circ} \mathrm{C}$ for $4 \mathrm{~h}$, followed by centrifugation at $10,000 \mathrm{~g}$ for $20 \mathrm{~min}$ at $4^{\circ} \mathrm{C}$. The purification of the lectins was carried out using established methods [6]. The supernatant was submitted to affinity chromatography on a Sephadex G-50 column $(5 \times 25 \mathrm{~mm})$, equilibrated with $0.9 \% \mathrm{NaCl}$ containing $5 \mathrm{mM} \mathrm{CaCl}_{2}$ and $5 \mathrm{mM} \mathrm{MnCl}_{2}$. Then the column was washed using the same buffer at a flow rate of $1 \mathrm{~mL} / \mathrm{min}$. The bound lectin was eluted with $0.1 \mathrm{M}$ glycine, $\mathrm{pH} 2.6$, dialyzed extensively against distilled water, and lyophilized. The purity of each lectin was monitored by SDS-PAGE, as described by Laemmli [17].

2.3. Artemia Lethality Test. Lectins were dissolved in artificial seawater at a concentration of $200 \mu \mathrm{g} / \mathrm{mL}$. The assay was performed boarding 24 well Linbro plates in which each well contained 10 Artemia nauplii in a final volume of $2 \mathrm{~mL}$. Lectin solution was added to the wells at final concentrations of $12.5,25,50$, or $100 \mu \mathrm{g} / \mathrm{mL}$. The experiments were performed in triplicate, and negative control wells contained $2 \mathrm{~mL}$ of artificial seawater with 10 Artemia nauplii. Another control group, which consisted of (bovine serum albumin) BSA at the same lectins concentration, was too included. After $24 \mathrm{~h}$, the number of dead nauplii in each well was counted. From these data was calculated the percentage of death at each concentration and the $\mathrm{LC}_{50}$ value by probit analysis as described by Finney [18].

2.4. Blocking the ConBr CRD. A solution of $200 \mu \mathrm{g} / \mathrm{mL}$ purified ConBr was incubated in artificial seawater containing $0.1 \mathrm{M} \alpha$-methyl mannoside for $1 \mathrm{~h}$ at $37^{\circ} \mathrm{C}$. That solution was then assayed in the Artemia lethality test at final concentrations of $12.5,25,50$, or $100 \mu \mathrm{g} / \mathrm{mL}$ ConBr. After $24 \mathrm{~h}$, the number of dead nauplii was counted. The percentage of death and the $\mathrm{LC}_{50}$ value were calculated by probit analysis as described by Finney [18].

2.5. FITC-Labeled Lectin. FITC-labeled lectins were prepared in inhibition buffer $(0.1 \mathrm{M}$ D-mannose in $0.1 \mathrm{M}$ carbonate-bicarbonate buffer, $\mathrm{pH} 9.0$ ), conjugation buffer (0.1 M carbonate-bicarbonate buffer, $\mathrm{pH} 9.0)$, and washing buffer (phosphate-buffered saline: $0.01 \mathrm{M}$ sodium phosphate buffer, $0.027 \mathrm{M} \mathrm{KCl}$ and $0.15 \mathrm{M} \mathrm{NaCl}, \mathrm{pH} 7.4$ ). Initially, the lectins were dissolved in inhibition buffer and incubated at $37^{\circ} \mathrm{C}$ for $1 \mathrm{~h}$. Then, $250 \mu \mathrm{L}$ fluorescein isothiocyanate (FITC) $(500 \mu \mathrm{g} / \mathrm{mL}$ in conjugation buffer) was added dropwise. The solution was incubated for $2 \mathrm{~h}$ at room temperature under gentle stirring. Subsequently, unconjugated FITC was separated from FITC lectin by size exclusion chromatography using a Sephadex G-25 column previously equilibrated and eluted with washing buffer. The absorbance of all fractions was determined at $280 \mathrm{~nm}$ (protein) and $495 \mathrm{~nm}$ (FITC) to verify chromatographic efficiency. The FITC-labeled lectins were then dialyzed against $0.1 \mathrm{M}$ acetic acid for $1 \mathrm{~h}$ to remove the blocker carbohydrate and extensively dialyzed against distilled water. The BSA was coupled to FITC following the same steps used to lectins, without the use of inhibition buffer.

2.6. Lectin Fluorescence Microscopy. Briefly, the shrimp were incubated with FITC-lectins or FITC-BSA $(50 \mu \mathrm{g} / \mathrm{mL})$ and kept overnight. The shrimp were then washed 3 times in phosphate-buffered saline, placed on slides, and observed under a fluorescence microscope (Eclipse E200/epifluorescence, Nikon, Tokyo, Japan) equipped with a digital camera (DS-2Mv, Nikon, Tokyo, Japan). Images were acquired with NIS-Elements software version 2.3 (Nikon, Tokyo, Japan). The resolution of all acquired images was 5.0 Mpixel (Media Cybernetics, Silver Spring, MDI, USA).

2.7. Structural Analysis. The CRD volume of all lectins was calculated using the Q-SiteFinder program [19]. Briefly, crystal structures of C. ensiformis (PDB code: 1JBC), C. brasiliensis (PDB code: 3JU9), and C. maritima (PDB code: 2OW4) were obtained from Protein Data Bank (PDB) repository [20]. Atomic coordinates from C. boliviana (CBol) and $C$. grandiflora (ConGF) are in-house data and remain under publication. The structures were visualized using COOT [21] and PyMol [22]. 


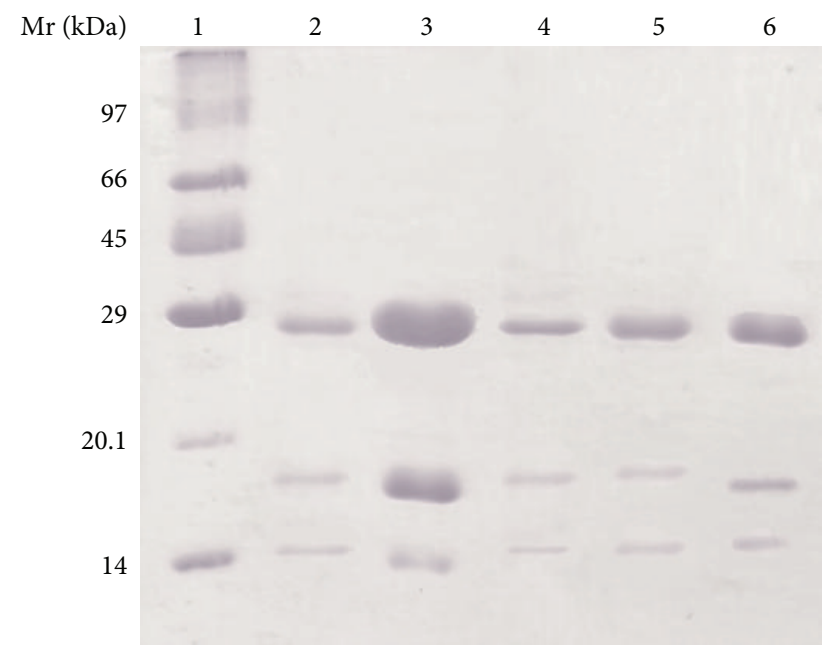

Figure 1: SDS-PAGE: (1) molecular mass markers (phosphorylase b, $97 \mathrm{kDa}$; bovine serum albumin, $66 \mathrm{kDa}$; ovalbumin, $45 \mathrm{kDa}$; carbonic anhydrase, $29 \mathrm{kDa}$; trypsin inhibitor, $20.1 \mathrm{kDa}$; and $\alpha$ lactalbumin, $14 \mathrm{kDa}$ ); (2) ConBr (3) ConA, (4) ConM, (5) ConBol, and (6) ConGF.

\section{Results and Discussion}

The SDS-PAGE of ConBr, ConA, ConM, ConBol, and ConGF showed a pattern of subunits characteristic of the lectins from the Diocleinae subtribe. The proteins migrated through the electric field and were separated into three bands consisting of the full-length intact polypeptide chain ( $\alpha$-chain) and two fragments, $\beta$ and $\gamma$ (Figure 1).

Canavalia lectins exhibited a range of different toxicities toward Artemia nauplii. The $\mathrm{LC}_{50}$ values for ConA, ConBr, ConM, ConBol, and ConGF are shown in Table 1. The least toxic lectin in this assay was ConA, which had a $\mathrm{LC}_{50}$ of $376.48 \mu \mathrm{g} / \mathrm{mL}$. The most toxic was $\mathrm{ConBr}$, which exhibited $\mathrm{LC}_{50}$ of $54.38 \mu \mathrm{g} / \mathrm{mL}$. When preincubated with $\alpha$-methyl mannoside, the $\mathrm{LC}_{50}$ of ConBr increased from $54.38 \mu \mathrm{g} / \mathrm{mL}$ to $337.75 \mu \mathrm{g} / \mathrm{mL}$ (Table 1 ).

Toxicological studies have been conducted on all kinds of bioactive molecules and natural extracts [23, 24]. The Artemia lethality test has been used as a preliminary toxicity assay commonly performed before other bioassays that detect anticancer, antiviral, insecticide, pesticide, and anti-HIV activity; as such, the Artemia lethality test is very suitable for biotechnological purposes and the evaluation of bioactive compounds. Until now, only a small number of lectins have been evaluated in the Artemia lethality test. In most instances, lectins such as CSL-2 and PNL-2 have shown high toxicity [25-27]. In contrast, lectins such as SejaBL exhibit low toxicity [28].

It has been published elsewhere that to achieve more solubility of the lectins to perform this kind of biological tests the use of DMSO is suitable $[14,27]$. Although DMSO has been reported to have low toxicity [29], this does not exclude the possibility that the Artemia toxicity is not affected by the addition of DMSO in these previous reports. Santos et al. [27] studying the toxicity of ConA-like lectins in the
TABLE 1: $\mathrm{LC}_{50}$ and percentage of dead nauplii in different concentrations of lectins.

\begin{tabular}{|c|c|c|c|}
\hline Lectins & $\begin{array}{c}\text { Concentration } \\
(\mu \mathrm{g} / \mathrm{mL})\end{array}$ & \% Lethality $24 \mathrm{~h}$ & $\mathrm{LC}_{50} 24 \mathrm{~h}$ \\
\hline \multirow{3}{*}{ ConA } & 12.5 & 20 & \multirow{4}{*}{$376.48( \pm 72.25)$} \\
\hline & 25 & 20 & \\
\hline & 50 & 30 & \\
\hline \multirow{5}{*}{ ConM } & 100 & 27 & \\
\hline & 12.5 & 7 & \multirow{4}{*}{$146.55( \pm 27.34)$} \\
\hline & 25 & 37 & \\
\hline & 50 & 33 & \\
\hline & 100 & 37 & \\
\hline \multirow{3}{*}{ ConBol } & 12.5 & 20 & \multirow{4}{*}{$218.13( \pm 38.50)$} \\
\hline & 25 & 20 & \\
\hline & 50 & 33 & \\
\hline \multirow{5}{*}{$\mathrm{ConBr}$} & 100 & 33 & \\
\hline & 12.5 & 43 & \multirow{4}{*}{$54.38( \pm 23.48)$} \\
\hline & 25 & 40 & \\
\hline & 50 & 50 & \\
\hline & 100 & 60 & \\
\hline \multirow{4}{*}{ ConGF } & 12.5 & 3 & \multirow{4}{*}{$110.51( \pm 8.79)$} \\
\hline & 25 & 10 & \\
\hline & 50 & 13 & \\
\hline & 100 & 43 & \\
\hline \multirow{4}{*}{ ConBr + sugar } & 12.5 & 17 & \multirow{4}{*}{$337.75( \pm 53.54)$} \\
\hline & 25 & 27 & \\
\hline & 50 & 27 & \\
\hline & 100 & 27 & \\
\hline
\end{tabular}

presence of DMSO found out a $\mathrm{LC}_{50}$ for ConBr of $15.4 \mu \mathrm{g} / \mathrm{mL}$. The present work obtained an $\mathrm{LC}_{50}$ of $54.38 \mu \mathrm{g} / \mathrm{mL}$ in an assay that contained no DMSO (Table 1). Increased toxicity of ConBr in the presence of DMSO in the work by Santos et al. [27] may be due to a synergy between the two compounds. Ramos et al. [10] reported that a highly toxic lectin isolated from Abrus pulchellus had an $\mathrm{LC}_{50}$ of $3.5 \mu \mathrm{g} / \mathrm{mL}$ without the addition of DMSO. The findings pointed out the fact that it is possible to carry on studies of lectin toxicity without the use of DMSO.

Preincubation of ConBr with $\alpha$-methyl mannoside showed that the carbohydrate-recognition domain is involved in the toxic effect of the lectin on brine shrimp. When preincubated with the carbohydrate, the $\mathrm{LC}_{50}$ of ConBr increased from $54.38 \mu \mathrm{g} / \mathrm{mL}$ to $337.75 \mu \mathrm{g} / \mathrm{mL}$ (Table 1).

Microscopy confirmed that lectins bound to Artemia nauplii (Figure 2). All lectins bound to a similar area of the organism and this area represents the digestive tract of the nauplii. The binding in this area was probably due to specific carbohydrate recognition, since the addition of $\alpha$ methyl mannoside reduced the binding of the FITC-labeled lectins to the digestive tract of the nauplii (data not shown). 

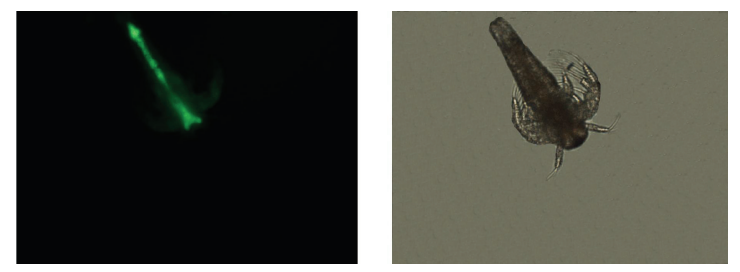

(a)
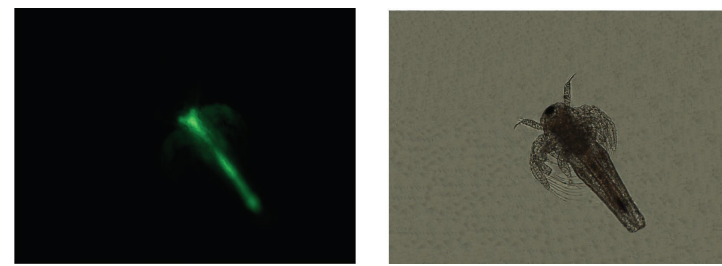

(b)
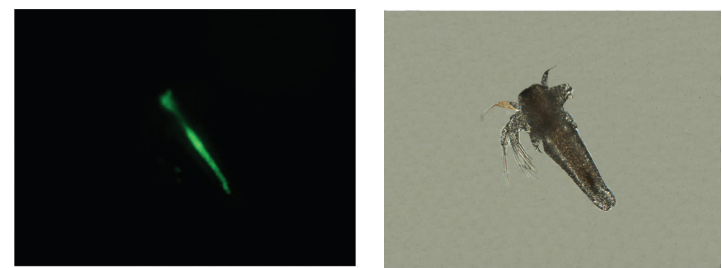

(c)
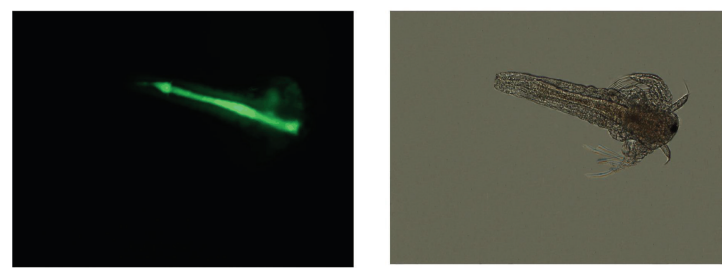

(d)
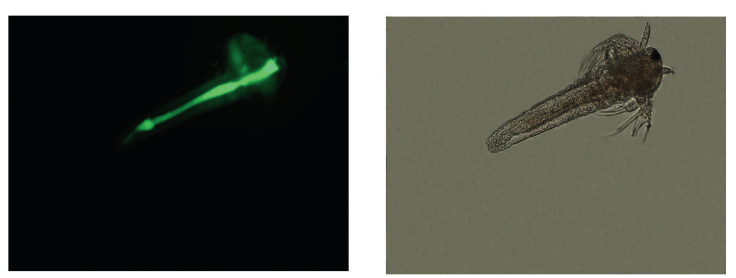

(e)
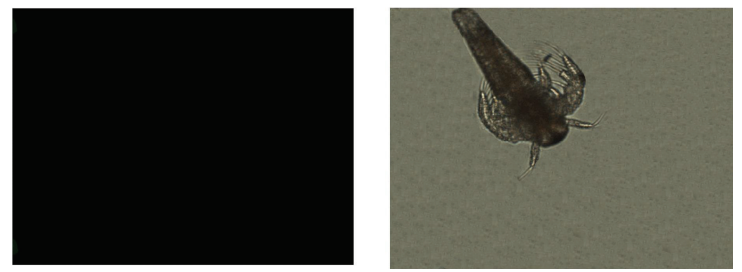

(f)

FIgURE 2: Binding of FITC-labeled lectins to Artemia nauplii detected by fluorescence microscopy. The green color indicates the presence of FITC-labeled lectins in the digestive tract of the animal. (a) FITC-ConBr; (b) FITC-ConA; (c) FITC-ConBol; (d) FITC-ConM; (e) FITCConGF; and (f) FITC-BSA. The same images were also acquired in bright field without fluorescence excitation. 


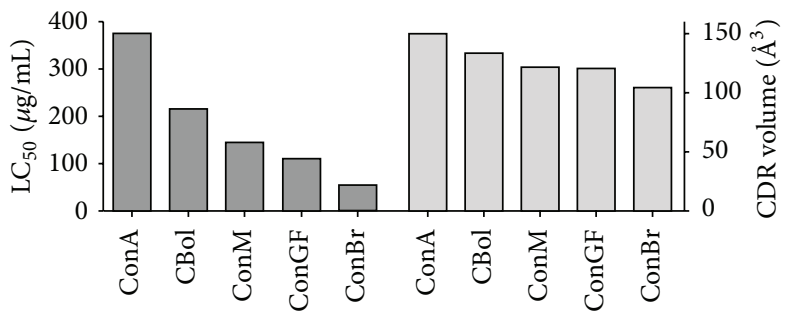

FIGURE 3: Relationship between CRD volumes and toxicity of the Canavalia lectins.

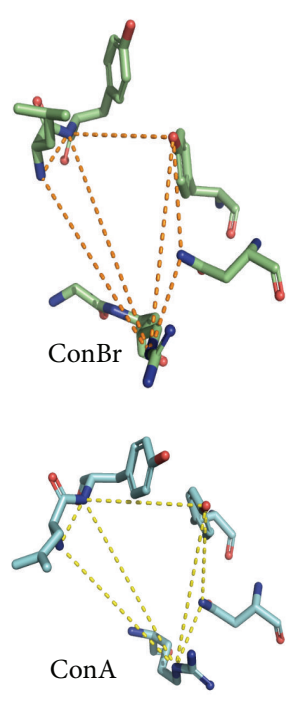

(a)

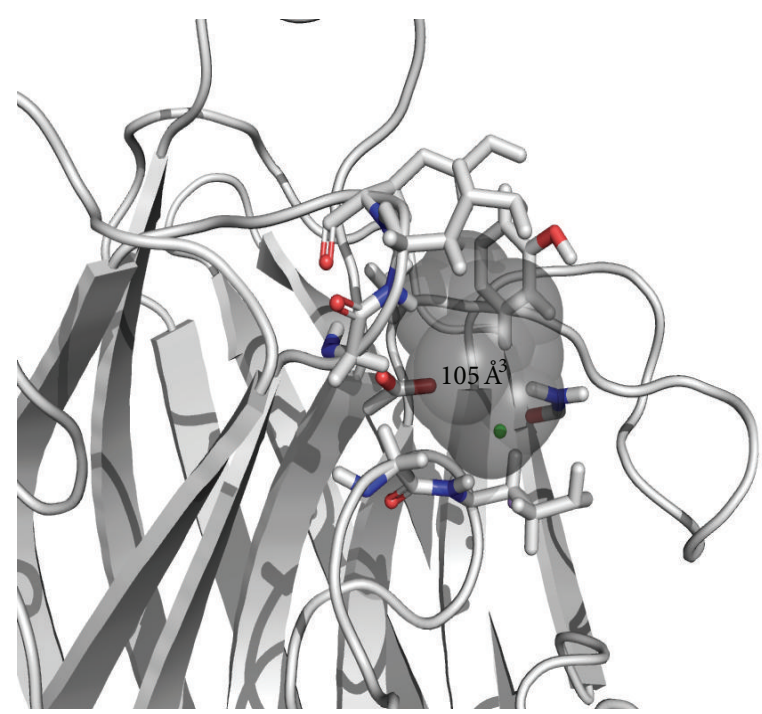

(b)

FIgURE 4: (a) Distances between residues comprising the CRD of ConBr (green) and ConA (blue). (b) ConBr structure with highlighted residues that comprise its CRD in sticks surrounding spheres, which comprise the volume of the CRD.

The exact mechanism by which lectins play its toxicity on Artemia is still unclear; however, fluorescence tests showed the presence of lectins in the digestive tract of Artemia nauplii, suggesting that the surface of the digestive tract is extensively glycosylated (Figure 2). Previous studies have shown that plant lectins have an affinity for the surface of gut epithelial cells of mammals and insects [30-32]. These lectins when attached to the surface of the gut epithelial cells may cause an antinutritional action, inhibiting the absorption of nutrients or occasionally causing toxic effects, leading to necrosis in the gut cells [30].

Despite the high structural similarity shared by Canavalia lectins, significant differences were seen when the toxicity was assessed on Artemia nauplii. Key distances between residues comprising the CRD will determine its shape and hence the volume of each domain (Figures 3 and 4 ). Such characteristics directly impact the carbohydrate recognition and elicitation of biological effects $[33,34]$.

Interestingly, a direct relationship between the CRD volume and the toxicity level of lectins on Artemia nauplii was achieved. Among the tested lectins, ConBr was the most toxic, with $\mathrm{LC}_{50}$ of $54.38 \mathrm{mg} / \mathrm{mL}$. ConBr has a CRD volume of $105 \AA^{3}$ (the smallest CRD volume among the tested lectins).
On the other hand, ConA had an $\mathrm{LC}_{50}$ of $376.48 \mathrm{mg} / \mathrm{mL}$ and has a CRD volume of $151 \AA^{3}$ (the largest volume among the tested lectins).

Thus, it was observed that the relationship between $\mathrm{LC}_{50}$ and CRD volume is directly proportional (Figure 3 ). That is, when the CRD volume is small the $\mathrm{LC}_{50}$ is low. Therefore, if the lectins are ordered according to $\mathrm{LC}_{50}$ and CRD volume, the following sequence is obtained: ConA $\left(\mathrm{LC}_{50}\right.$ of $376.48 \mu \mathrm{g} / \mathrm{mL}$; CRD volume of $\left.151 \AA^{3}\right)>$ Con$\operatorname{Bol}\left(218.13 \mu \mathrm{g} / \mathrm{mL} ; 134 \AA^{3}\right)>\operatorname{ConM}\left(146.55 \mu \mathrm{g} / \mathrm{mL} ; 122 \AA^{3}\right)$ $>\operatorname{ConGF}\left(110.51 \mu \mathrm{g} / \mathrm{mL} ; 121 \AA^{3}\right)>\operatorname{ConBr}(54.38 \mu \mathrm{g} / \mathrm{mL}$; $\left.105 \AA^{3}\right)$.

Despite the structural similarities shared between Canavalia lectins and hence in the specificities for carbohydrates, the term "ConA-like" is not suitable when the issue refers to biological activities. Cavada et al. [6] reported that minor changes in the overall structure of some lectins lead to different biological activities. These differences arise from changes in three major physicochemical parameters: binding specificity for complex carbohydrates, the $\mathrm{pH}$-dependent oligomerization state (dimer-tetramer equilibrium), and the relative orientation of the carbohydrate-binding sites. The smallest CRD volume 
of ConBr among other Canavalia lectins has been shown to be the major reason of its lower activation of nitric oxide synthase in aortic endothelial cells [35]. In this study, the smallest CRD volume of $\mathrm{ConBr}$ proved to be the major reason of its high toxicity on brine shrimp.

Although Canavalia lectins are structurally similar, minor structural changes are the basis by which they differ from each other. Such modifications change the threedimensional structure of these proteins (as in the CRD arrangement) and hence may cause significant differences in several biological activities. Thus, the structural analysis of lectins in response to a biological activity can provide valuable information concerning their mechanisms of action.

\section{Conclusions}

According to the data reported in this study, ConBr is the most toxic on brine shrimp, while ConA is the least toxic, and ConBol, ConM, and ConGF exhibit intermediate levels of toxicity. Concerning the experimental methodology, it is a new approach to establish the toxicity of lectins on Artemia nauplii. In addition, new insights were provided about the role of lectins structure and its effect on viability of brine shrimp, which probably will contribute in further studies.

\section{Acknowledgments}

This study was supported by grants from Conselho Nacional de Desenvolvimento Científico e Tecnológico (CNPq), Coordenação de Aperfeiçoamento de Pessoal de Nível Superior (CAPES), Fundação Cearense de Apoio ao Desenvolvimento Científico e Tecnológico (FUNCAP). The authors thank the American Journal Experts (http://www.journalexperts.com/) for helping with the English language editing of the paper. Kyria Santiago Nascimento, Edson Holanda Teixeira, Benildo Sousa Cavada, and Alexandre Holanda Sampaio are senior investigators of $\mathrm{CNPq}$.

\section{References}

[1] N. Sharon and H. Lis, Lectins, Kluwer Academic Publishers, Dordrecht, The Netherlands, 3rd edition, 2003.

[2] W. J. Peumans and E. J. van Damme, "Lectins as plant defense proteins," Plant Physiology, vol. 109, no. 2, pp. 347-352, 1995.

[3] D. C. Kilpatrick, "Animal lectins: a historical introduction and overview," Biochimica et Biophysica Acta, vol. 1572, no. 2-3, pp. 187-197, 2002.

[4] N. Sharon and H. Lis, "History of lectins: from hemagglutinins to biological recognition molecules," Glycobiology, vol. 14, no. 11, pp. 53R-62R, 2004.

[5] E. J. M. van Damme, W. J. Peumans, A. Barre, and P. Rougé, "Plant lectins: a composite of several distinct families of structurally and evolutionary related proteins with diverse biological roles," Critical Reviews in Plant Sciences, vol. 17, no. 6, pp. 575692, 1998.

[6] B. S. Cavada, T. Barbosa, S. Arruda, T. B. Grangeiro, and M. Barral-Netto, "Revisiting proteus: do minor changes in lectin structure matter in biological activity? Lessons from and potential biotechnological uses of the Diocleinae subtribe lectins," Current Protein and Peptide Science, vol. 2, no. 2, pp. 123-135, 2001.

[7] B. M. Vose and G. D. Bonnard, "Limiting dilution analysis of the frequency of human $\mathrm{T}$ cells and large granular lymphocytes proliferating in response to interleukin 2. I. The effect of lectin on the proliferative frequency and cytotoxic activity of cultured lymphoid cells," The Journal of Immunology, vol. 130, no. 2, pp. 687-693, 1983.

[8] K. Urech, G. Schaller, P. Ziska, and M. Giannattasio, "Comparative study on the cytotoxic effect of viscotoxin and mistletoe lectin on tumour cells in culture," Phytotherapy Research, vol. 9, no. 1, pp. 49-55, 1995.

[9] J. M. Alvarez, M. O. de Landazuri, G. D. Bonnard, and R. B. Herberman, "Cytotoxic activities of normal cultured human T cells," The Journal of Immunology, vol. 121, no. 4, pp. 1270-1275, 1978.

[10] M. V. Ramos, D. M. Mota, C. R. Teixeira, B. S. Cavada, and R. A. Moreira, "Isolation and partial characterisation of highly toxic lectins from Abrus pulchellus seeds," Toxicon, vol. 36, no. 3, pp. 477-484, 1998.

[11] P. Sorgeloos, C. R. van der Wielen, and G. Persoone, "The use of Artemia nauplii for toxicity tests-a critical analysis," Ecotoxicology and Environmental Safety, vol. 2, no. 3-4, pp. 249255, 1978.

[12] G. Persoone, Proceeding of the International Symposium on Brine Shrimp, Artemia Salina, vol. 1-3, University Press, Wetteren, Belgium, 1980.

[13] J. L. Carballo, Z. L. Hernández-Inda, P. Pérez, and M. D. GarcíaGrávalos, "A comparison between two brine shrimp assays to detect in vitro cytotoxicity in marine natural products," $B M C$ Biotechnology, vol. 2, no. 17, pp. 1-5, 2002.

[14] F. Pervin, M. M. Hossain, S. Khatun et al., "Comparative cytotoxicity study of six bioactive lectins purified from pondweed (Potamogeton nodosus Poir) rootstock on brine shrimp," Journal of Medical Sciences, vol. 6, no. 6, pp. 999-1002, 2006.

[15] J.-C. Ho, C.-M. Chen, and L.-C. Row, "Oleanane-type triterpenes from the flowers, pith, leaves, and fruit of Tetrapanax papyriferus," Phytochemistry, vol. 68, no. 5, pp. 631-635, 2007.

[16] P. Vanhaecke, G. Persoone, C. Claus, and P. Sorgeloss, "Proposal for a short-term toxicity test with Artemia nauplii," Ecotoxicology and Environmental Safety, vol. 5, no. 3, pp. 382-387, 1981.

[17] U. K. Laemmli, "Cleavage of structural proteins during the assembly of the head of bacteriophage T4," Nature, vol. 227, no. 5259, pp. 680-685, 1970.

[18] D. J. Finney, Probit Analysis, vol. 18, University Press, Cambridge, UK, 3rd edition, 1971.

[19] A. T. R. Laurie and R. M. Jackson, "Q-SiteFinder: an energybased method for the prediction of protein-ligand binding sites," Bioinformatics, vol. 21, no. 9, pp. 1908-1916, 2005.

[20] F. C. Bernstein, T. F. Koetzle, G. J. B. Williams et al., "The protein data bank: a computer based archival file for macromolecular structures," Journal of Molecular Biology, vol. 112, no. 3, pp. 535542,1977

[21] P. Emsley and K. Cowtan, "Coot: model-building tools for molecular graphics," Acta Crystallographica Section D, vol. 60, no. 1, pp. 2126-2132, 2004.

[22] W. L. DeLano, The PyMOL Molecular Graphics System, DeLano Scientific, San Carlos, Calif, USA, 2002.

[23] J. E. Thompson, R. P. Walker, and D. J. Faulkner, "Screening and bioassays for biologically-active substances from forty marine 
sponge species from San Diego, California, USA," Marine Biology, vol. 88, no. 1, pp. 11-21, 1985.

[24] A. V. Krishnaraju, T. V. N. Rao, D. Sundararaju, M. Vanisree, H. S. Tsay, and G. V. Subbaraju, "Assessment of bioactivity of Indian medicinal plants using brine shrimp (Artemia salina) lethality assay," International Journal of Applied Science and Engineering, vol. 3, no. 2, pp. 125-134, 2005.

[25] I. M. Vasconcelos, B. S. Cavada, R. A. Moreira, and J. T. A. Oliveira, "Purification and partial characterization of a lectin from the seeds of Dioclea guianensis," Journal of Food Biochemistry, vol. 15, no. 2, pp. 137-154, 1991.

[26] M. A. Ali, M. A. Sayeed, and N. Absar, "Antibacterial activity and cytotoxicity of three lectins purified from Cassia fistula Linn. seeds," Journal of Medical Sciences, vol. 3, no. 3, pp. 240244, 2003.

[27] A. F. D. Santos, B. S. Cavada, B. A. M. D. Rocha, K. S. D. Nascimento, and A. E. G. Sant'Ana, "Toxicity of some glucose/mannose-binding lectins to Biomphalaria glabrata and Artemia salina," Bioresource Technology, vol. 101, no. 2, pp. 794798, 2010.

[28] A. F. M. Vaz, R. M. P. B. Costa, A. M. M. A. Melo et al., "Biocontrol of Fusarium species by a novel lectin with low ecotoxicity isolated from Sebastiania jacobinensis," Food Chemistry, vol. 119, no. 4, pp. 1507-1513, 2010.

[29] R. Vignes, "Dimethyl Sulfoxide (DMSO): a "new" clean, unique, superior solvent," in Proceedings of the American Chemical Society Annual Meeting, pp. 20-24, Washington, DC, USA, 2000.

[30] A. Pusztai and S. Bardocz, "Biological effects of plant lectins on the gastrointestinal tract: metabolic consequences and applications," Trends in Glycoscience and Glycotechnology, vol. 8, no. 41, pp. 149-165, 1996.

[31] N. Sauvion, C. Nardon, G. Febvay, A. M. R. Gatehouse, and Y. Rahbé, "Binding of the insecticidal lectin Concanavalin A in pea aphid, Acyrthosiphon pisum (Harris) and induced effects on the structure of midgut epithelial cells," Journal of Insect Physiology, vol. 50, no. 12, pp. 1137-1150, 2004.

[32] K. Miyake, T. Tanaka, and P. L. McNeil, "Lectin-based food poisoning: a new mechanism of protein toxicity," PloS ONE, vol. 2, no. 1, article e687, 2007.

[33] M. J. B. Bezerra, N. V. F. C. Rodrigues, A. F. Pires et al., "Crystal structure of Dioclea violacea lectin and a comparative study of vasorelaxant properties with Dioclea rostrata lectin," The International Journal of Biochemistry \& Cell Biology, vol. 45, no. 4, pp. 807-815, 2013.

[34] M. A. de Vasconcelos, C. O. Cunha, F. V. S. Arruda et al., "Lectin from Canavalia brasiliensis seeds (conbr) is a valuable biotechnological tool to stimulate the growth of Rhizobium tropici in vitro," Molecules, vol. 17, no. 5, pp. 5244-5254, 2012.

[35] E. H. S. Bezerra, B. A. M. Rocha, C. S. Nagano et al., "Structural analysis of ConBr reveals molecular correlation between the carbohydrate recognition domain and endothelial NO synthase activation," Biochemical and Biophysical Research Communications, vol. 408, no. 4, pp. 566-570, 2011. 

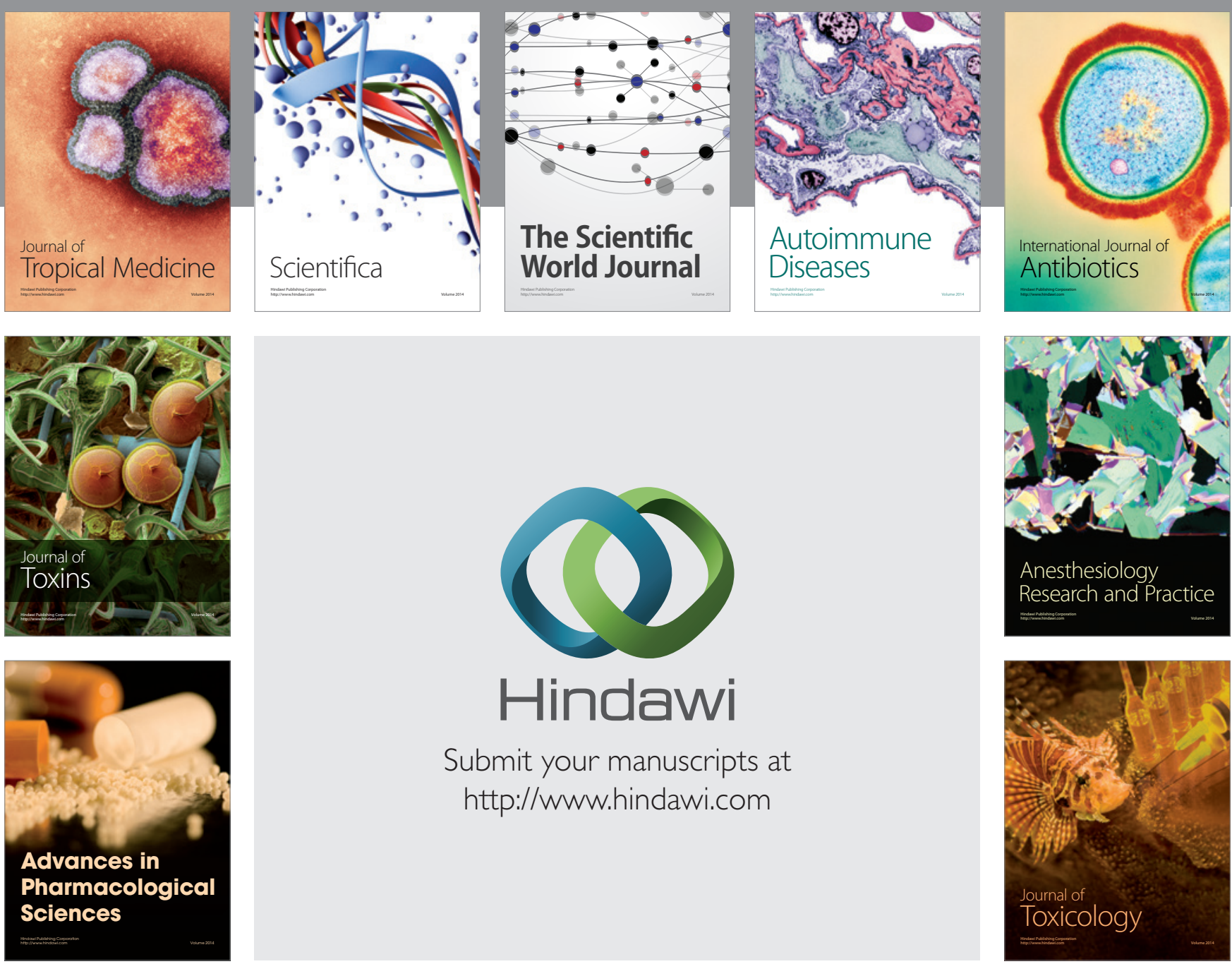

\section{Hindawi}

Submit your manuscripts at

http://www.hindawi.com
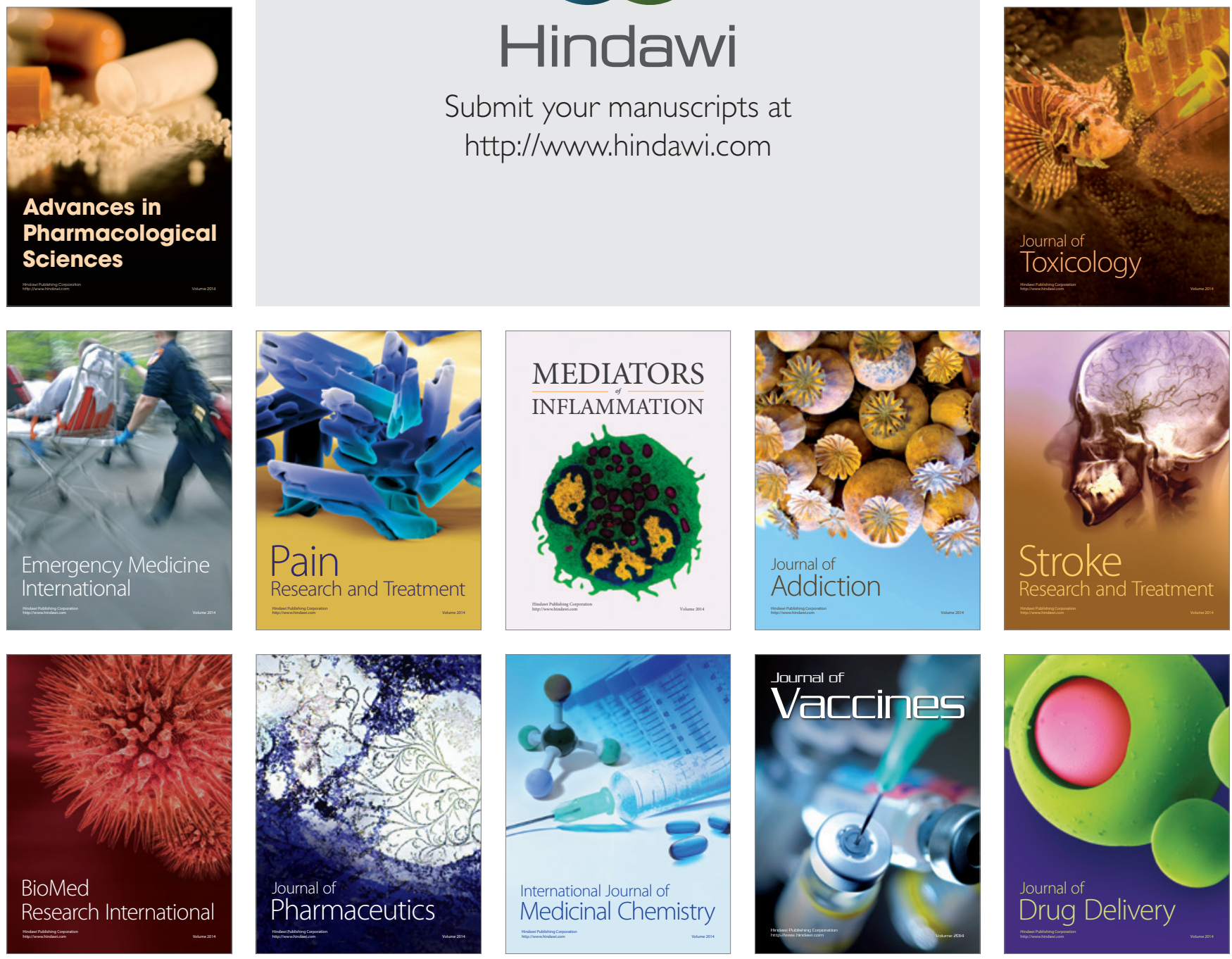